\title{
Effect of Polyamine on Pigmentation, Reactive Oxidative Species and Antioxidant under Drought in Maize (Zea mays L.)
}

\author{
Sharmin Akter ${ }^{1}$, Md. Golam Rasul ${ }^{1}$, Mohammad Zakaria ${ }^{2}$, Md. Mahathir Sarker ${ }^{3}$, \\ Irin Sultana Nila ${ }^{1}$, Sudipta Dutta ${ }^{1}$, Md. Masudul Haque ${ }^{4}$, Md. Motiar Rohman ${ }^{5 *}$
}

${ }^{1}$ Department of Genetics and Plant Breeding, Bangabandhu Sheikh Mujibur Rahman Agricultural University, Gazipur-1706, Bangladesh ${ }^{2}$ Department of Horticulture, Bangabandhu Sheikh Mujibur Rahman Agricultural University, Gazipur-1706, Bangladesh ${ }^{3}$ BRAC BARDC, Gazipur-1701, Bangladesh

${ }^{4}$ Chittagong University, Chittagong-4331, Bangladesh

${ }^{5}$ Plant Breeding Division, Bangladesh Agricultural Research Institute, Gazipur, Bangladesh

\section{A R T I C L E I N F O}

\section{Research Article}

Received 30 August 2017

Accepted 17 January 2018

Keywords:

Oxidative stress

Abiotic stress

Polyethylene Glycol

Antioxidants

AsA-GSH cycle

*Corresponding Author:

E-mail: motiar_1@yahoo.com

A B S T R A C T

To examine polyamines (PAs) effect in modulating the drought induced by polyethylene glycol (PEG) in maize (Zea mays L.) seedlings (variety Khoibhutta, 8 day seedlings grown in petri dish in incubator) were subjected to 20\% PEG (polyethylene glycol) followed by $20 \mu \mathrm{mol}$ PAs, Putrescine (Put), Spermidine (Spd) and Spermine (Spm) with PEG solution for 48 hours. Sharp decrease in Relative Water Content (RWC), Chl $a$, Chl $b$, carotenoid (Car) and total pigment content was observed under drought compared to control condition, while PAs application reversed their decreasing trends. PEG significantly increased Reactive Oxidative Species (ROS) [superoxide $\left(\mathrm{O}_{2}{ }^{\circ}\right)$ and $\mathrm{H}_{2} \mathrm{O}_{2}$ ], Methyl Glyoxal (MG), Melondialdehyde (MDA) and Lipoxigenase (LOX) activity, while Pas decreased the contents considerably (except MG) as compared to those under drought. Drought increased proline content, which was further augmented in PA treatments. PAs failed to incline glyoxalase's (Gly-I and Gly-II) activities, reduced under PEG. The activity and western blot confirmed the accumulation of Glutathione $S$ Transferase (GST) under drought, but PAs failed to augment the activity. Ascorbic Acid (AsA) and Glutathione (GSH) got oxidized into Dehydroascorbate (DHA) and oxidized Glutathione (GSSG) under drought but PAs effectively maintained homeostasis. Superoxide Dismutase (SOD), Peroxidase (POD), Ascorbate Peroxidase (APX), Glutathione Peroxidase (GPX), Monodehydroascorbatereductase (MDHAR), Dehydroascorbatereductase (DHAR), and Glutathione Reductase (GR) inclined in drought stressed seedlings, while Catalase (CAT) activity decreased under drought. PAs addition increased SOD, POD, GPX, CAT, MDHAR, and GR activities, but declined DHAR activity. These findings suggested important role of PAs in increasing tolerance under short term drought by modulating antioxidant effect.

DOI: https://doi.org/10.24925/turjaf.v6i7.799-811.1493

\section{Introduction}

Drought changes plant metabolic activity, which leads to enhanced production of ROS (reactive oxygen species) comprising free radicals such as superoxide anion $\left(\mathrm{O}_{2}{ }^{--}\right)$, hydroxyl radical $\left({ }^{\circ} \mathrm{OH}\right)$, as well as non-radical molecules like hydrogen peroxide $\left(\mathrm{H}_{2} \mathrm{O}_{2}\right)$, singlet oxygen $\left({ }^{1} \mathrm{O}_{2}\right)$, and so forth which genesis follows a sequential reduction of molecular oxygen $\left(\mathrm{O}_{2}\right)$ by high-energy exposure or, electron-transfer reactions (Sharma et al., 2012). ROS functions are lipid peroxidation, protein oxidation, nucleic acid damage, enzyme inhibition, damage in photosynthetic pathway, and activation of programmed cell death (PCD) pathway, and ultimate cell death (Sharma and Dubey, 2005). There are two different mechanisms by which the plants regulate their intercellular ROS concentrations. One is by enabling the fine modulation of low levels of ROS for signaling purpose, and another one is by proceeding the detoxification of excess ROS, especially during stress (Mitter, 2002). ROS scavenging or, detoxification is accomplished by an efficient antioxidative system comprising of the non-enzymic as well as enzymic antioxidants (Noctor and Foyer, 1998). The enzymic antioxidants include SOD, CAT, GPX, enzymes of ascorbate-glutahione (AsA-GSH cycle) like APX, MDHAR, DHAR, and GR (Noctor and Foyer, 1998). AsA, GSH (reduced glutathione), tocopherols, and phenolics serve as potent non-enzymic antioxidants. However, many advanced research have found positive 
influence of PAs, aliphatic nitrogen compounds, in stress tolerance mechanism through increased ROS scavenging via increase in antioxidative activities, as they are involved in the regulation of physical and chemical properties of membranes, nucleic acids structure and functions, and modulation of enzyme activities (Galston and Kaur Sawhney, 1990). Three major PAs, found in all living cells are diamineputrescine (Put), the triaminespermidine (Spd), and the tetraminespermine (Spm). It has been reported that chloroplasts and photosynthetic sub-complexes including thylakoids and PSII membranes are enriched with three major PAs, while PSII (photosystem II) core and the reaction center of PSII are exclusively rich in Spm (Kotzabasis et al., 1993; Navakoudis et al., 2003) and detoxify effectively cytocompartments by influencing the effectiveness of enzymic and non-enzymic antioxidants. Furthermore, genetic transformation with PAs biosynthetic genes encoding arginine Decarboxylase (ADC), Ornithine Decarboxylase (ODC), S-Adenosylmethionine Decarboxylase (SAMDC) or, Spd Synthase (SPDS) improved stress tolerance mechanism in different environmental and pathogenic adversity (Liu et al., 2007). That is why, to know the role of exogenous application of PAs in improving stress tolerance through regulating enzymic and non-enzymic antioxidants is gaining importance to understand the underlying stress tolerance mechanism under abiotic stress including drought.

\section{Materials and Methods}

\section{Plant Materials and Stress Treatments}

Maize variety "Khiovutta" seedlings were grown in incubator. Eight days seedlings were subjected to 5 treatments namely Control, $20 \%$ of PEG, 20\% PEG +20 $\mu \mathrm{mol}$ Put, $20 \%$ PEG $+20 \mu \mathrm{mol}$ Spd and 20\% PEG +20 $\mu \mathrm{mol} \mathrm{Spm} \mathrm{for} 48$ hours (Plate 1). The experiments were repeated three times each containting three replications. After 48 hours exposure of maize seedling, data were recorded on different parameters.

\section{Relative Water Content (RWC) Estimation}

RWC was estimated according to Barrs and Weatherley (1962). Fresh weight (FW), turgid weight (TW) and dry weight (DW) of leaves were recorded. The RWC was calculated by the following formula: RWC (\%) $=(\mathrm{FW}-\mathrm{DW}) \times 100 /(\mathrm{TW}-\mathrm{DW})$.

\section{Chlorophyll (Chl) and Carotenoid (Car) Determination}

Extraction and measurement of $\mathrm{Chl}$ and Car were performed according to the method of Arnon (1949). Chl and Car were calculated using the formulas below and expressed in $\mathrm{mg} \mathrm{g}^{-1}$ fresh weight (FW).

$$
\begin{array}{ll}
\mathrm{Chl} a\left(\mathrm{mg} \mathrm{g}^{-1} \mathrm{l}\right) & =(0.0127) \times\left(\mathrm{A}_{663}\right)-(0.00269) \times\left(\mathrm{A}_{645}\right) \\
\mathrm{Chl} b\left(\mathrm{mg} \mathrm{g}^{-1}\right) & =(0.0229) \times\left(\mathrm{A}_{645}\right)-(0.00468) \times\left(\mathrm{A}_{663}\right) \\
\operatorname{Car}\left(\mathrm{mg} \mathrm{g}^{-1}\right) & =\mathrm{A}_{470}+\left(0.114 \times \mathrm{A}_{663}-0.638 \times \mathrm{A}_{645}\right)
\end{array}
$$

\section{Assay of Proline}

Prolines' colorimetric determination proceeded according to Bates et al. (1973) based on prolines' reaction with ninhydrin.

\section{Estimation of ROS}

Superoxide radical was determined according to the method of Elstner and Heupel (1976) with modifications. Leaves $(0.3 \mathrm{~g})$ were homogenized in $3 \mathrm{ml}$ of $65 \mathrm{mM}$ (KP) buffer ( $\mathrm{pH} \mathrm{7.8)} \mathrm{and} \mathrm{then} \mathrm{centrifuged} \mathrm{at} 4{ }^{\circ} \mathrm{C}$ and 5,000 $\times g$ for $10 \mathrm{~min}$. The supernatants $(0.75 \mathrm{ml})$ were mixed with $0.675 \mathrm{ml}$ of $65 \mathrm{mM} \mathrm{K-P}$ buffer $(\mathrm{pH} 7.8)$ and $0.07 \mathrm{ml}$ of $10 \mathrm{mM}$ hydroxylamine chlorhydrate and placed at $25^{\circ} \mathrm{C}$. After $20 \mathrm{~min}, 0.375 \mathrm{ml}$ of $17 \mathrm{mM}$ sulfanilamide and $0.375 \mathrm{ml}$ of $7 \mathrm{mM} \alpha$-naphthylamine were added, and the mixture was placed at $25^{\circ} \mathrm{C}$ for another $20 \mathrm{~min}$ before it was mixed with $2.25 \mathrm{ml}$ of ether. The absorbance was measured at $530 \mathrm{~nm}$ and the $\mathrm{O}_{2}{ }^{--}$concentration was calculated from a standard curve of $\mathrm{NaNO}_{2} \cdot \mathrm{H}_{2} \mathrm{O}_{2}$ which was assayed according to $\mathrm{Yu}$ et al. (2003). LOX activity was measured following Doderer et al. (1992). Lipid peroxidation was measured by a decomposed product of the peroxidized poly-unsaturated fatty acid component of the membrane lipid, using TBA (thiobarbituric acid) as the reactive material following the method of Heath and Packer (1968).

Determination of Enzymes of Glyoxalase System (GlyI and Gly-II)

Gly-I assay was carried out according to Yadav et al. (2005). Briefly, the assay mixture contained $100 \mathrm{mM} \mathrm{K-P}$ buffer ( $\mathrm{pH}$ 7.0), $15 \mathrm{mM}$ magnesium sulfate, $1.7 \mathrm{mM}$ $\mathrm{GSH}$, and $3.5 \mathrm{mM} \mathrm{MG}$ in a final volume of $0.7 \mathrm{ml}$. The reaction was started by the addition of $\mathrm{MG}$, and the increase in absorbance was recorded at $240 \mathrm{~nm}$ for $1 \mathrm{~min}$. The activity was calculated using the extinction coefficient of $3.37 \mathrm{mM}^{-1} \mathrm{~cm}^{-1}$. Gly-II activity was determined according to Principato et al. (1987) by monitoring the formation of GSH at $412 \mathrm{~nm}$ for $1 \mathrm{~min}$. The reaction mixture contained $100 \mathrm{mM}$ Tris- $\mathrm{HCl}$ buffer (pH 7.2), $0.2 \mathrm{mM}$ DTNB \{5,5'-dithio-bis (2-nitrobenzoic acid) , and $1 \mathrm{mM}$ SLG (S-D-lactoylglutathione) in a final volume of $1 \mathrm{ml}$. The reaction was started by the addition of SLG, and the activity was calculated using the extinction coefficient of $13.6 \mathrm{mM}^{-1} \mathrm{~cm}^{-1}$. MG estimation was done following Wild et al. (2012).

Extraction of Soluble Protein and Assay of Enzymatic Antioxidant Activities

Fresh leaves of maize seedlings were extracted by homogenizing in an equal volume of $25 \mathrm{mM}$ Tris- $\mathrm{HCl}$ $\left.\begin{array}{llllll}\text { buffer } & (\mathrm{pH} & 8.0\end{array}\right)$ containing $1 \quad \mathrm{mM}$ EDTA (ethylenediaminetetraacetic acid), 1\% (w/v) AsA, and $10 \%(\mathrm{w} / \mathrm{v})$ glycerol with mortar pestle. The homogenate was centrifuged at $11,500 \times g$ for $15 \mathrm{~min}$, and the supernatant was used as a soluble protein solution for enzyme assay. SOD activity was determined using the method of Spitz and Oberley (1989). CAT activity was measured according to the method of Csiszar et al. (2007) by monitoring the decrease of absorbance at $240 \mathrm{~nm}$ for 1 min caused by the decomposition of $\mathrm{H}_{2} \mathrm{O}_{2}$. APX activity was assayed following the method of Nakano and Asada (1981). GPX activity was measured as described by Elia et al. (2003) using $\mathrm{H}_{2} \mathrm{O}_{2}$ as a substrate. MDHAR activity was determined by the method of Hossain et al. (2010). DHAR activity was determined by the procedure of Nakano and Asada (1981). POD activity was estimated according to Hemeda and Klein (1990). GR activity was 
measured by the method of Hossain et al. (2010). GSTs separation, purification, and polyclonal antibody preparation were done following the method of Rohman et al. (2010).

\section{Extraction and Assay of Non-Enzymic Antioxidant}

Maize leaves ( $0.5 \mathrm{~g}$ fresh weight) were homogenized in $3 \mathrm{ml}$ ice-cold acidic extraction buffer (5\% metaphosphoric acid containing $1 \mathrm{mM}$ EDTA) using a mortar and pestle. Homogenates were centrifuged at $11,500 \times g$ for $15 \mathrm{~min}$ at $4^{\circ} \mathrm{C}$, and the supernatant was collected for analysis of AsA and GSH. AsA content was assayed following the method of Huang et al. (2005). The glutathione pool was assayed according to $\mathrm{Yu}$ et al. (2003), utilizing $0.40 \mathrm{ml}$ of aliquots of supernatant neutralized with $0.6 \mathrm{ml}$ of $0.5 \mathrm{M} \mathrm{K}-\mathrm{P}$ buffer ( $\mathrm{pH} 7.0$ ). Oxidized glutathione (GSSG) was determined after removal of GSH by 2-vinylpyridine derivatization. Reduced glutathione (GSH) was found by deduction of GSSG from total glutathione. Specific standard curves with GSH and GSSG were used.

\section{Determination of Protein}

The protein concentration in the leaf extracts was determined according to the method of Bradford (1976) using BSA (bovine serum albumin) as a protein standard.

\section{SDS-PAGE and Western Blotting}

SDS-PAGE (Sodium Dodecyl Sulphate Polyacrylamide Gel Electrophoresis) was done by the method of Laemmli (1970). The western blot was done following the protocol of Perkin-Elmer Life Science Inc. For protein detection, silver staining was done for detecting as little as $5 \mathrm{mg}$ protein.

\section{Statistical Analysis}

All data obtained was analyzed by SAS (Version 9.1) program following complete randomized design (CRD) and the mean differences were compared by least significant (LSD) tests. $\mathrm{P}$ values $<0.05$ were considered to be significant.

\section{Results}

Relative water content decreased when seedlings are subjected to PEG induced drought, but it augmented in PA $(\mathrm{PEG}+\mathrm{Put}, \mathrm{PEG}+\mathrm{Spd}$, and $\mathrm{PEG}+\mathrm{Spm})$ treated plants by $15 \%, 17 \%$, and $13 \%$, respectively when compared to drought condition (Figure 1A). Drought decreased Chla content by $34 \%$ compared to normal growing environment (Figure 1B), while Put, Spd, and Spm increased Chla content by the level of $27 \%, 21 \%$, and $23 \%$, respectively over that in drought. $\mathrm{Chl} b$ content also decreased significantly (about 39\%) under PEG treatment (Figure 1C). However, when plants were subjected to Put, Spd, and Spm in PEG application, they reversed the decreasing tendency showing 39\%, 34\%, and $32 \%$, respective increase of Chl $b$ content. Like Chl, Car content decreased $(39 \%)$ during drought exposure (Figure 1D). PAs (Put, Spd, and Spm) supplementation were associated to induce Car by $15 \%, 11 \%$, and $11 \%$, respectively as compared to drought. In case of total pigment, significant loss was observed in drought stressed seedlings (Figure 1E). Through exogenous PAs application, total pigment was inclined $(27 \%$ by put, $25 \%$ by spd, and $24 \%$ by spm). Proline was accumulated in drought stressed seedlings by $34 \%$ as compared to control, while Put, Spd, and Spm further inclined the content by $12 \%, 22 \%$ and $17 \%$, respectively (Figure $1 \mathrm{~F}$ ). Formation rate of $\mathrm{O}_{2}{ }^{--}$became sharply higher $(73.9 \%)$ in seedlings subjected to drought while Put, Spd, and Spm treatments decreased the $\mathrm{O}_{2}{ }^{--}$content by $33 \%, 35 \%$, and $27 \%$, respectively (Figure 2A). Drought induced the content of $\mathrm{H}_{2} \mathrm{O}_{2}$ by $133 \%$ over control but Put, Spd, and Spm application decreased $\mathrm{H}_{2} \mathrm{O}_{2}$ content to a substantial level by $31 \%, 35 \%$, and 24\%, respectively (Figure 2B). Put showed higher effectiveness among the three PAs in decreasing $\mathrm{H}_{2} \mathrm{O}_{2}$ value through maintaining proper homeostatic balance. Drought augmented MDA contentas $111 \%$ higher as compared to that in control (Figure 2C). Spd treatment significantly decreased MDA content by $35 \%$ while Put and Spm decreased MDA level by $23 \%$ and $14 \%$, respectively. Substantial increase (90\%) in LOX activity was observed under drought as compared to control (Figure 2D). Put, Spd, and Spm treatment decreased the LOX activity by $29 \%, 40 \%$ and $36 \%$, respectively. $112 \%$ substantial increment in MG content was observed under drought condition (Figure 3A). However, MG content was decreased in presence of Put, Spd, and Spm to a negligible level by $10 \%, 5 \%$ and $6 \%$, respectively when compared to drought stress. Gly-I remained almost similar to those in normal growth condition (Figure 3B). Addition of Put, Spd, and Spm treatment in PEG also failed to increase Gly-I activity. Drought increased the Gly-II activity by $11 \%$ which was statistically similar to normal growth condition. Presence of PAs in PEG also failed to increase the activity (Figure 3C).

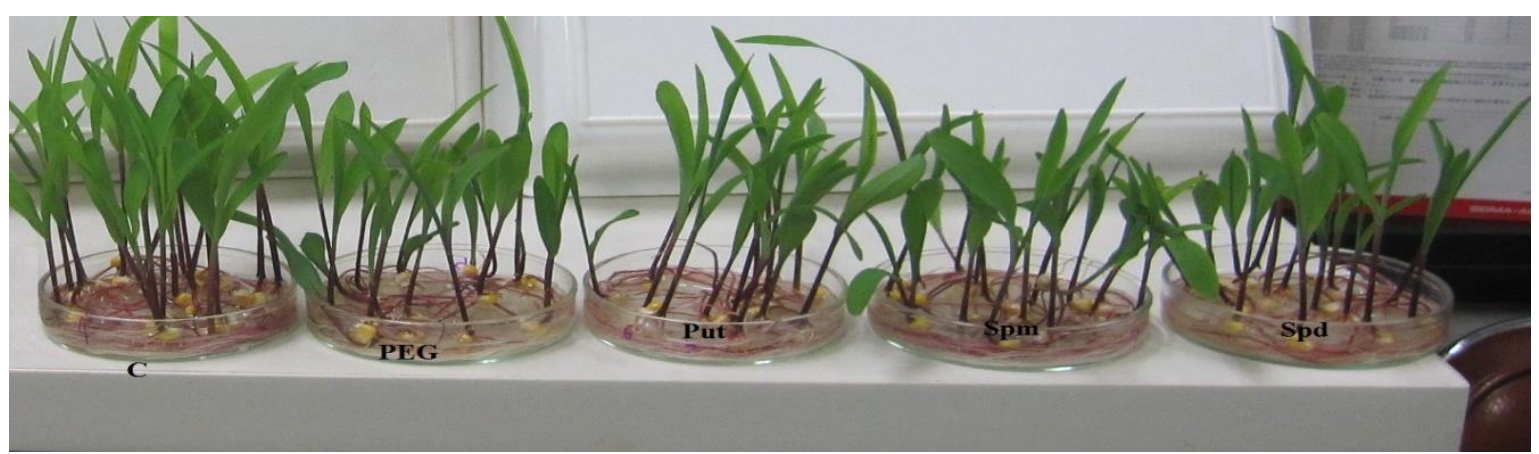

Plate 1 Different treatments: (a) Control, (b) PEG induced drought, (c) Put supplementation, (d) Spm supplementation, and (e) Spd application 

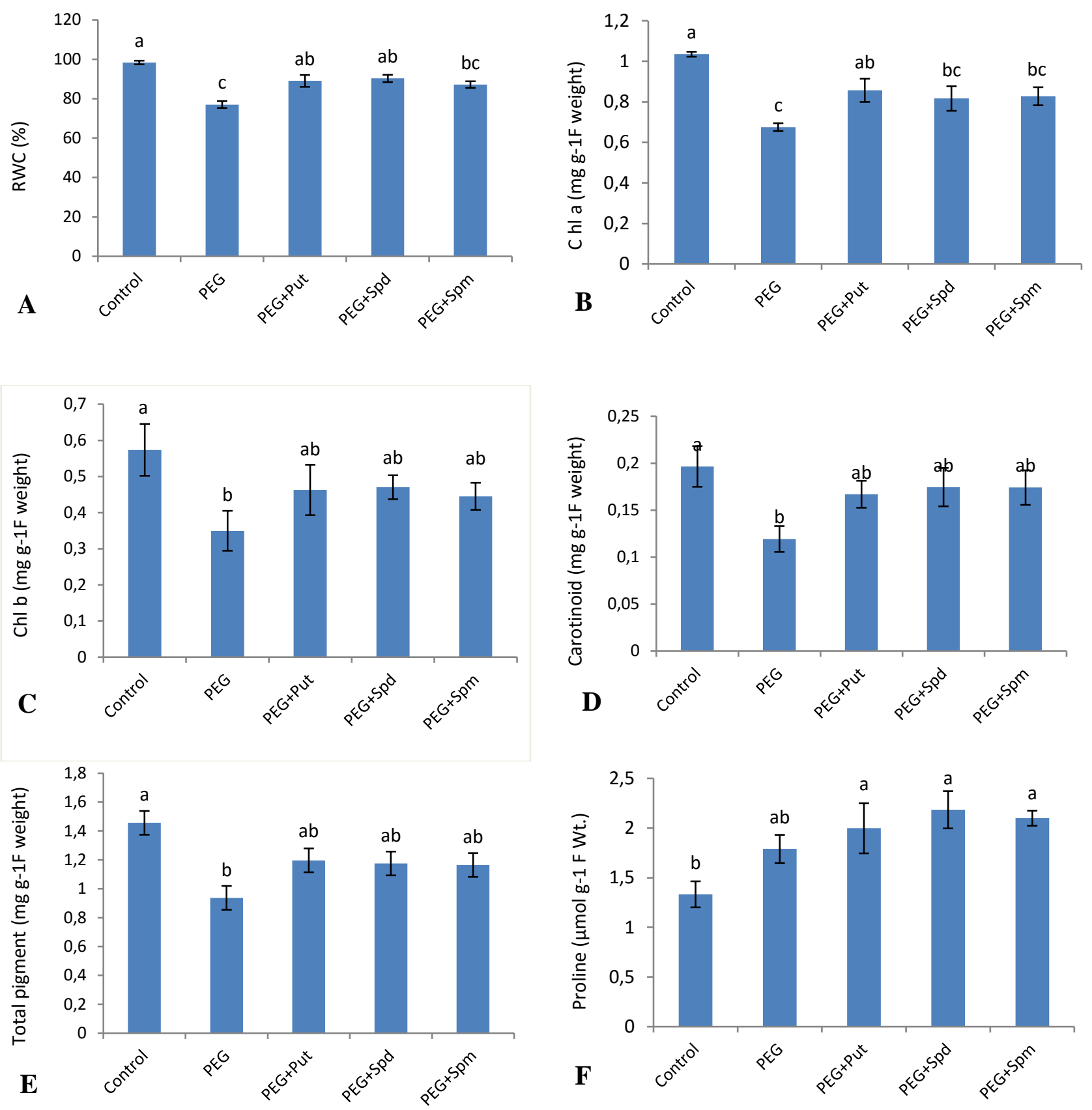

Figure 1 PAs Effect on RWC, Photosynthesis and Proline Content

(A) Relative Water Content, B) Chl $a$ content, (C) Chl $b$ content, (D) Carotenoid content, (E) Total pigment,

(F) Proline content in maize seedlings under control, PEG, PEG + Put, PEG + Spd, and PEG + Spm treatment

Drought decreased AsA content by $14 \%$ (Figure 4A) and simultaneously, 29\% increase was found in DHA content (Figure 4B). Put, Spd, and Spm treatment augmented AsA content by $12 \%, 11 \%$ and $10 \%$, respectively. Drought decreased the GSH content by $27 \%$ (Figure 4D). On the contrary, GSSG content increased by $63 \%$ (Figure 4E). Put, Spd, and Spm maintained higher GSH content by $15 \%, 12 \%$, and $11 \%$, respectively over the contents under drought. The redox state reported the activity of PAs in reducing the oxidation of GSH (Figure 4B, 4F). SOD activity was increasedby $38 \%$ when exposed to PEG (Figure 5A). Put, Spd, and Spm supplementation increased the activity by $12 \%, 14 \%$, and
$4 \%$, respectively. But, treatment effects on the basis of actuarial data were somewhat similar. POD activity increased under drought, but the level was statistically similar to that in control seedlings (Figure 5B). In Put, $\mathrm{Spd}$, and Spm treated seedlings, the activity was higher by $38 \%, 41 \%$, and $32 \%$ respectively, compared to drought. Seedlings under drought showed decreased CAT activity (18\%) compared to normal growth condition (Figure 5C). In PA treated seedlings, 22\%, 18\%, and 27\% higher activities were found by Put, Spd, and Spm compared to drought stressed seedlings, respectively. Significant increase in APX activity occurred under water stress over controlled condition (Figure 5D). However, remarkable 
changes were not found in the activity treated with PAs. GPX activity increased considerably $(144 \%)$ in drought stressed seedlings (Figure 5E). PAs treatments (Put and Spd) showed $12 \%$ and $17 \%$ higher activity than that in drought treated seedlings. $27 \%$ GR activity incremented was observed in drought than that in normal ambience (Figure 5F). Put, Spd, and Spm supplementation induced the activity by $19 \%, 21 \%$, and $10 \%$, respectively. No significant change in MDHAR activity occurred under drought ( $8 \%$ decrease) compared to control (Figure 5G).
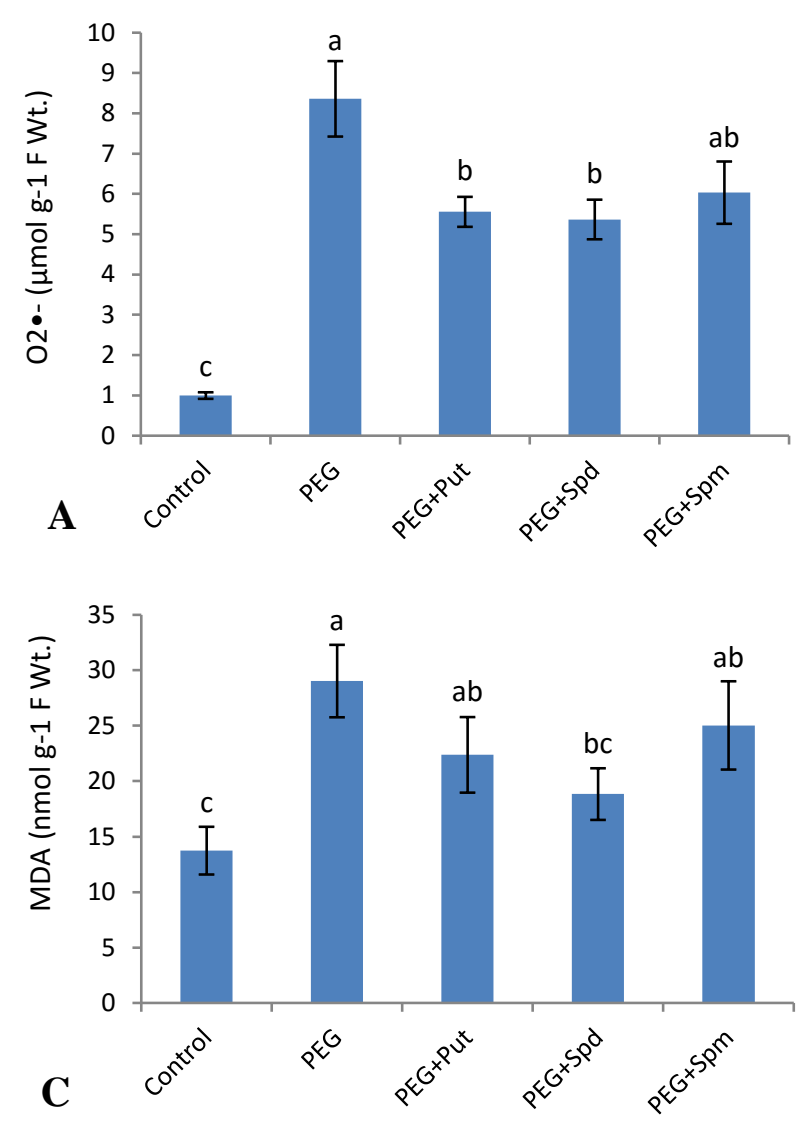

In PA treated seedlings, minute increase $(15 \%, 12 \%$, and $7 \%$ ) was observed compared to drought by Put, Spd, and Spm, respectively. DHAR activity was increased by $68 \%$ under drought (Figure 5H). Put, Spd, and Spm lowered the activity by $23 \%, 30 \%$, and $25 \%$, respectively than drought. In control seedlings, GST activity was $77.6 \mathrm{nmol}$ $\mathrm{min}^{-1} \mathrm{mg}^{-1}$ protein (Figure 6A). Under drought condition, GST showed $60 \%$ increment over controlled condition. However, all of PAs did not show remarkable changes in GST activities.
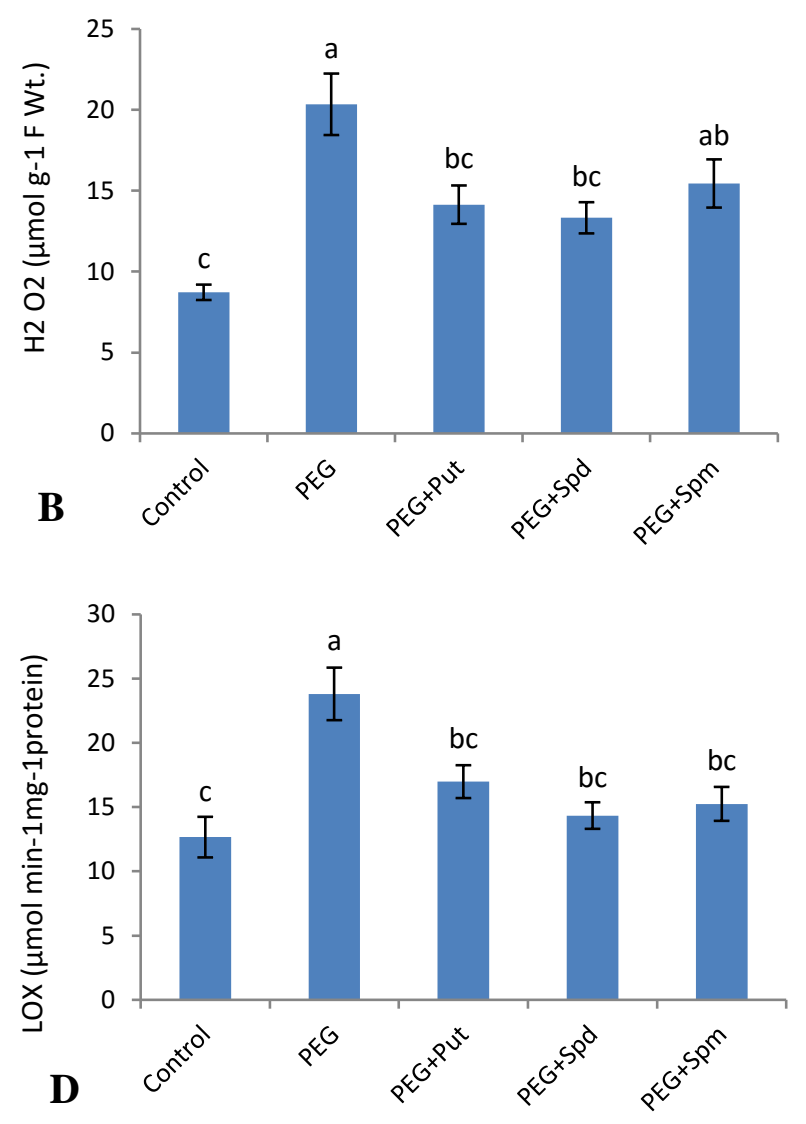

Figure 2 PAs Effect on ROS Activity

(A) Generation rate of $\mathrm{O}_{2}^{--}$, (B) Content of $\mathrm{H}_{2} \mathrm{O}_{2}$, (C) Content of MDA, and (D) LOX activity in maize seedlings under PEG induced drought in presence of PAs

\section{Discussion}

PAs Effect on RWC, Photosynthesis and Proline Content Present study observed sharp increase in RWC under drought (Figure 1A). D'Souza et al. (2014) and Rohman et al. (2016) also reported decrease in RWC during drought exposure. Water deficit inhibits root growth leading to decrease in its activity, associated with stomatal closure due to accumulation of abscisic acid in roots and guard cell, which may attribute to shrinking in RWC content (D'Souza et al., 2014). PAs delayed the loss of water under drought (Figure 1A). Similarly, D'Souza et al. (2014) found effective contribution of PAs, implying promising activity of Pas in enriching cytoplasmic $\mathrm{Ca}^{2+}$ concentration, which in turn activates the $\mathrm{K}^{+}$inward rectifier, thereby, evoke stomatal closure, attenuate transpiration rates and help maintaining turgor through balanced RWC content. Sharp decrease in photosynthetic activities was observed under drought (Figure 1B-E).
Under abiotic stress including drought, photosynthetic apparatus are the major components to be damaged (Gill and Tujeta, 2010). Several researches showed decreased amount of Chla, Chlb, Car, and total pigment (Paul and Paneerselvam, 2014; Anjum et al., 2011). Increased activity of different Chl degrading enzymes like chlorophyllase and peroxidase may act as key reason behind the decreased content of Chl (Paul and Paneerselvam, 2014; Abaaszadeh et al., 2007). Besides, under stress, SOD and AsA reduce $\mathrm{H}_{2} \mathrm{O}_{2}$ through "ironcatalyzed" reaction and induce $\mathrm{OH}^{\circ}$ production in thylakoids, which poses a great threat to Chl (Sharma et al., 2012). Car, which belongs to the lipophilic antioxidants, scavenge ${ }^{1} \mathrm{O}_{2}$, a cursor of oxidative degradation and evokes $\mathrm{Chl}$ molecule to prevent ${ }^{1} \mathrm{O}_{2}$ synthesis and protect photosynthetic apparatus. 

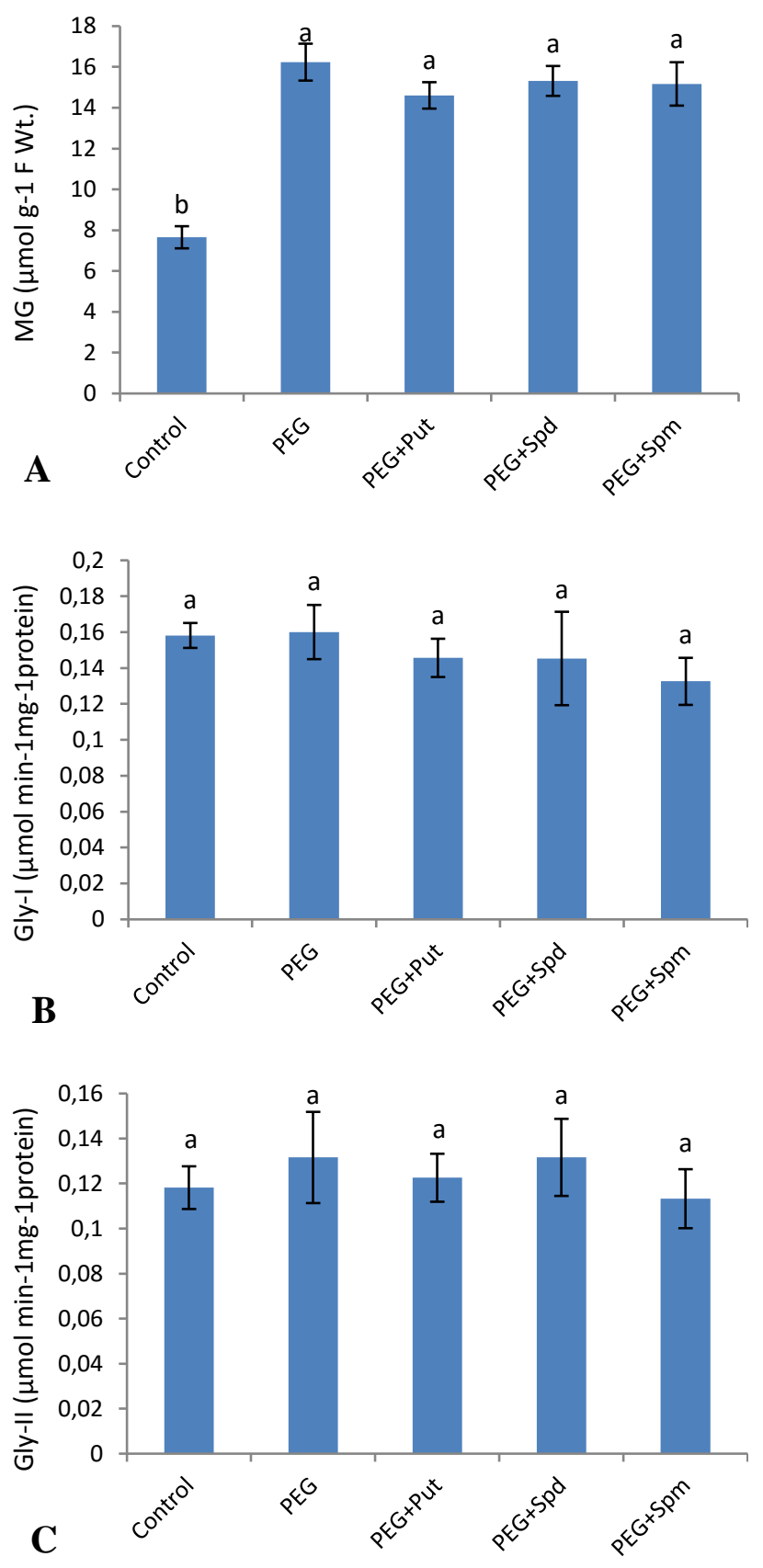

Figure 3 Effect of PAs on Glyoxalase System

(A) MG content, (B) Gly-I activity, and (C) Gly-II activity in maize seedlings under PEG induced drought in presence of Pas

The scavenging capability of Car is due to a chain of isoprene residues which permits easy energy uptake from excited molecules and release of excess energy as heat (Mittler, 2002). This observation having decreased Car content showed consistency with several previous reports (Logini et al., 1999; Agastian et al., 2000) under different stresses as reported in a number of plant species. However, PA application increased Chl (Figure 1B, 1C) and Car content (Figure 1D). Verma and Mishra (2005) also reported increased Car content under Put supplementation. Radhakrishnan and Lee (2014) also reported positive influence of Spd on pigment content in salt stressed cucumber plants. Proline is considered as an important parameter for evaluating stress tolerance capacity of plants (Delauney and Verma, 1993), as, during drought stress its accumulation serves as the early indicator (Sairam and Tyagi, 2004). Proline acts as an effective osmoprotectant, which can accumulate in a huge amount without insisting any kind of detrimental increase in ionic diffusion effect (Yancey et al., 1982). This experiment showed stiff increase of proline content during scarce water exposure regardless the PA application, which showed strong consistence with previous studies conducted by Parida et al., 2007 and Ramanjulu and Sudhakar, 2000. Increased proline accumulation may be due to the decreased proline dehydrogenase function, a catabolic enzyme of proline (Sundaresan and Sudhakaran, 1995; Lee and Liu, 1999). PAs application increased proline content implying effective PA impact on proline activity in alleviating ROS toxicity. This supposed impact may have a concern with the concept that metabolic pathways involved in proline and PA biosynthesis all require glutamate, arginine and ornithine as precursor (Aziz et al., 1995). Furthermore, taking comparative level of Put metabolism and Proline accumulation under consideration, a precursor-product relationship between Put and proline can be assumed (Aziz et al., 1995). Higher Spd effectiveness in proline synthesis among the three Pas collaborated with the findings of Roy Choudhry et al. (2011) reporting that exogenous Spd strongly incremented reducing sugar and proline level in salinity stress.

\section{PAs Effect on ROS}

Present observation reported increased content of ROS $\left(\mathrm{O}_{2}{ }^{--}\right.$and $\left.\mathrm{H}_{2} \mathrm{O}_{2}\right)$ under stressed condition (Figure 2A, 2B). Reason behind the enhanced production of ROS may be decreased assimilation of $\mathrm{CO}_{2}$, associated with altered photosynthetic activity via the Mehler reaction (Asada, 1999). PAs supplementation considerably decreased ROS content. The antioxidative effect of PAs is due to their anion and cation binding properties involving a radical scavenging function (Bors et al., 1998) and its ability to enervate both lipid peroxidation (Kitada et al., 1979) and metal catalyzed oxidative reactions (Tadolini, 1988). Supportively, Shen et al. (2000) reported that, Spd pretreatment of cucumber seedlings growing under chilling condition lowered ROS production. MDA, produced from unsaturated fatty acid peroxidation is responsible for cell membrane damage (Halliwell and Gutteridge, 1989). MDA serves as an indicator of membrane damage expressed as increased electrolyte leakage under stressed condition (Tiburcio et al., 1994). Present study showed increment in MDA content under drought (Figure 2C), which is in accordance with the investigation of Saleethong et al., 2011). Present study reported PAs effect to alleviate MDA content significantly (Figure 2C) and consisted with Zhang et al. (1996) and Xie et al. (1999). In this study, Spd seemed to be more effective in lowering MDA content (Figure 2C). Higher effectiveness of Spd in lowering MDA may be due to having highly propionate amino and imino group, which undergo conjugation with different negatively charged molecules like nucleic acids, proteins and phospholipids, and stabilize thylakoid membranes (Ahmad et al., 2012). 

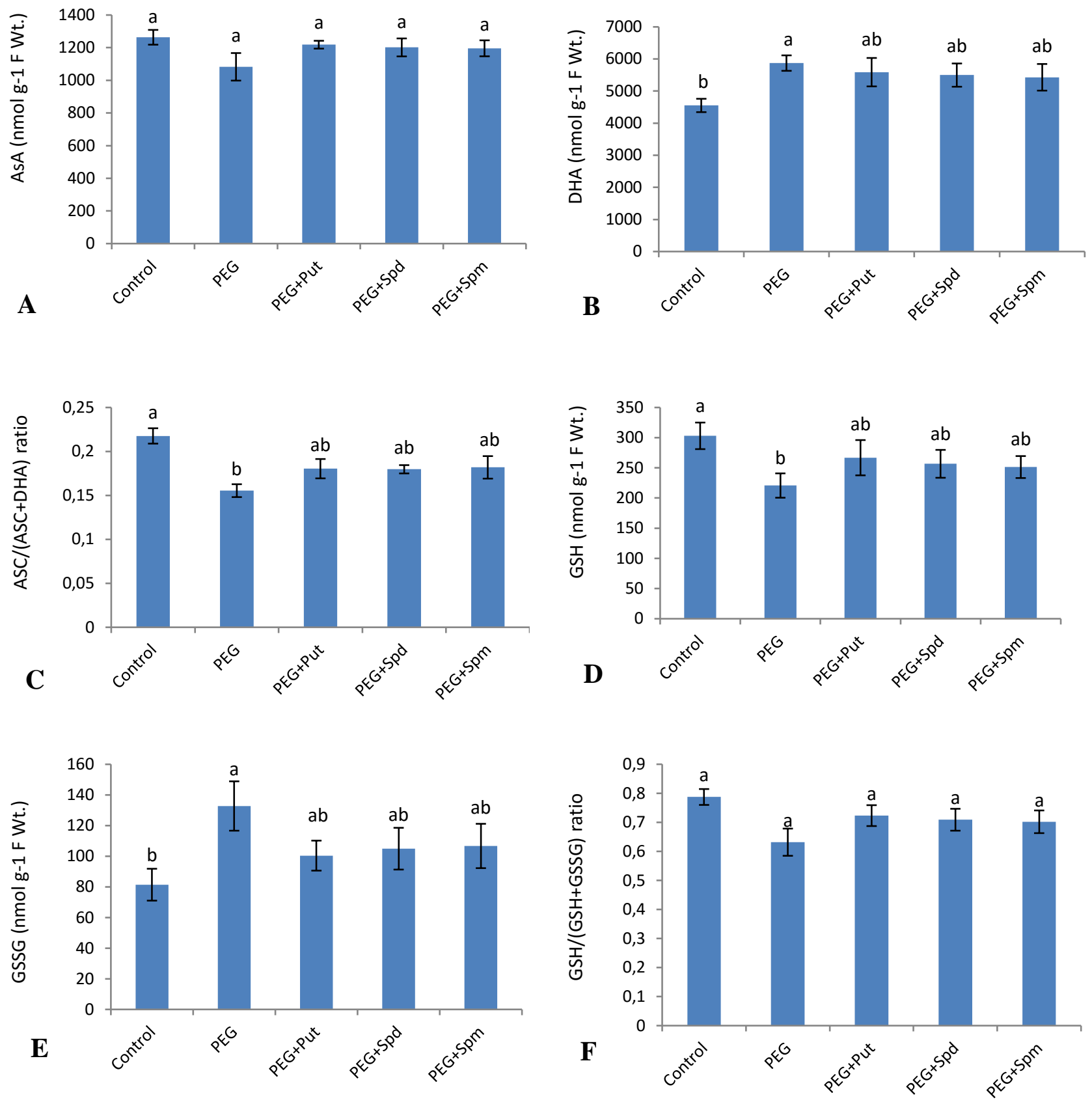

Figure 4 PAs Effect on Non-enzymic antioxidants

(A) Content of AsA, (B) DHA and (C) AsA redox (D) Content of GSH, (E) GSSG and (F) GSH redox in maize seedlings under PEG induced drought in presence of Pas

LOX activity was also correlated with increased MDA content in maize seedlings (Figure 2D). LOX is considered as causal agent to produce MDA which catalyzes the peroxidation of polyunsaturated fatty acids to their corresponding hydrogen peroxides (Doderer et al., 1992). Increased LOX activity was also reported in water stressed barley leaves (Kubis, 2006) and in senescing musk melon tissues (Lester, 2000). Stress induces membrane destabilization, causing increased membrane permeability, which in turn leads to accelerated LOX activation. Present experience showed higher activity of PAs specially Spd providing highest performance among all, in decreasing LOX activity. This observation consisted with the investigation of Chattopadhayay et al. (2002) and Lester (2000), which proposed effectiveness of exogenous application of Spd and Spm protecting cells against degradation by suppressing protease and RNAse functioning and thus maintaining cell membrane integrity.

\section{PAs Effect on Glyoxalase System}

The glyoxalase system, major pathway for cytotoxic MG metabolism includes the activity of two enzymes: glyoxalase 1 (Gly-I) and glyoxalase 2 (Gly-II). These enzymes use GSH as a co-factor to detoxify MG through a two-step reaction (Hossain et al., 2012; Thornalley, 1990). GSH and MG reaction forms hemithioacetal, which is then converted to S-D-lactoylglutahione (SLG) by Gly II and then Gly-I hydrolyzed SLG to D-lactate (Hossain et al., 2012). This coordinated function of Gly-I and Gly-II serves as an activator of stress tolerance mechanism (Hoque et al., 2007; Singla-Pareek et al., 2008). 

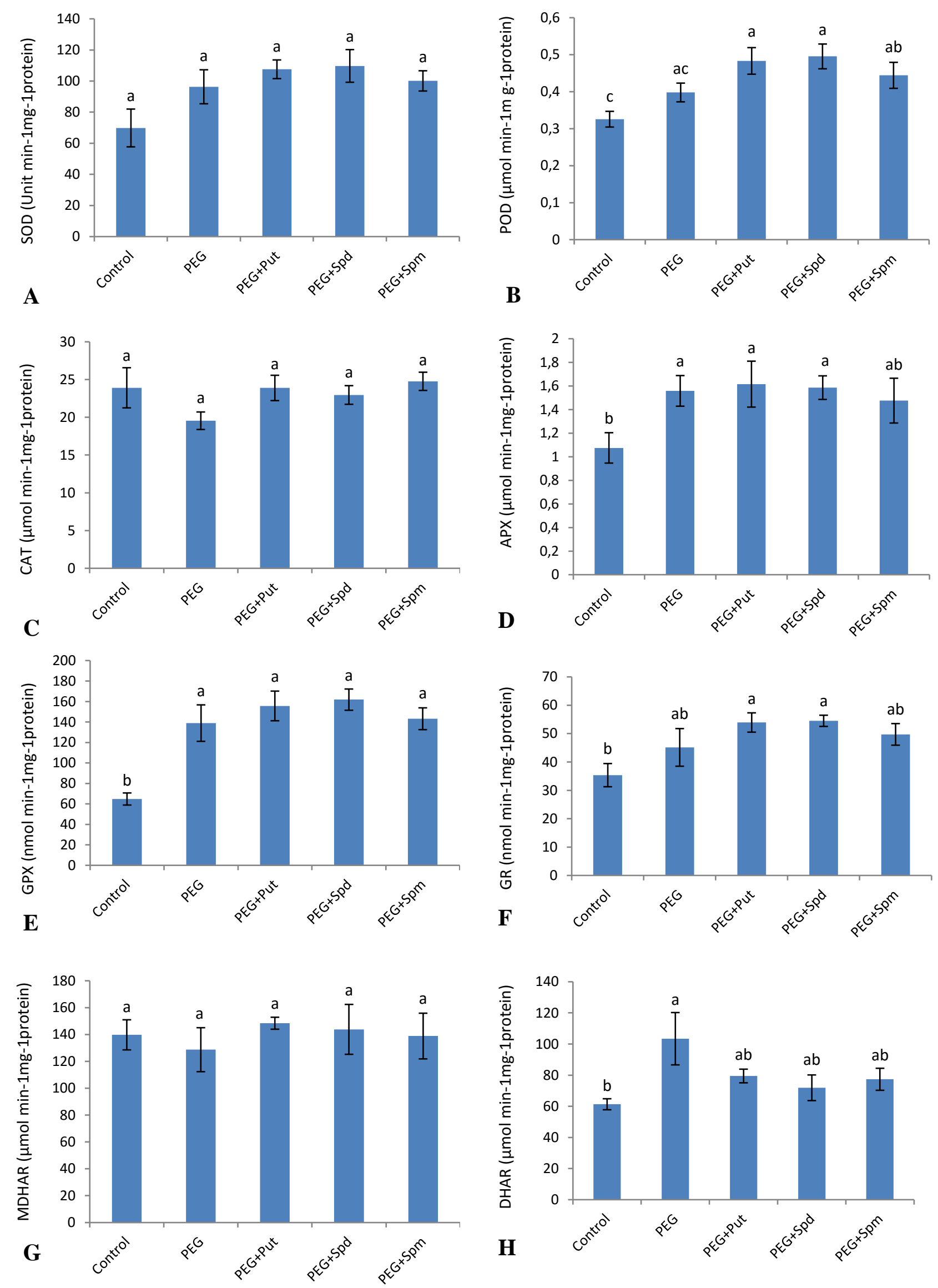

Figure 5 PAs Effect on Enzymic Antioxidants

(A) Activity of SOD, (B) Activity of POD, (C) Activity of CAT, (D) Activity of APX, (E) Activity of GPX, (F) Activity of GR, (G) Activity of MDHAR, and $(\mathrm{H})$ Activity of DHAR in maize seedlings under PEG induced drought in presence of Pas 

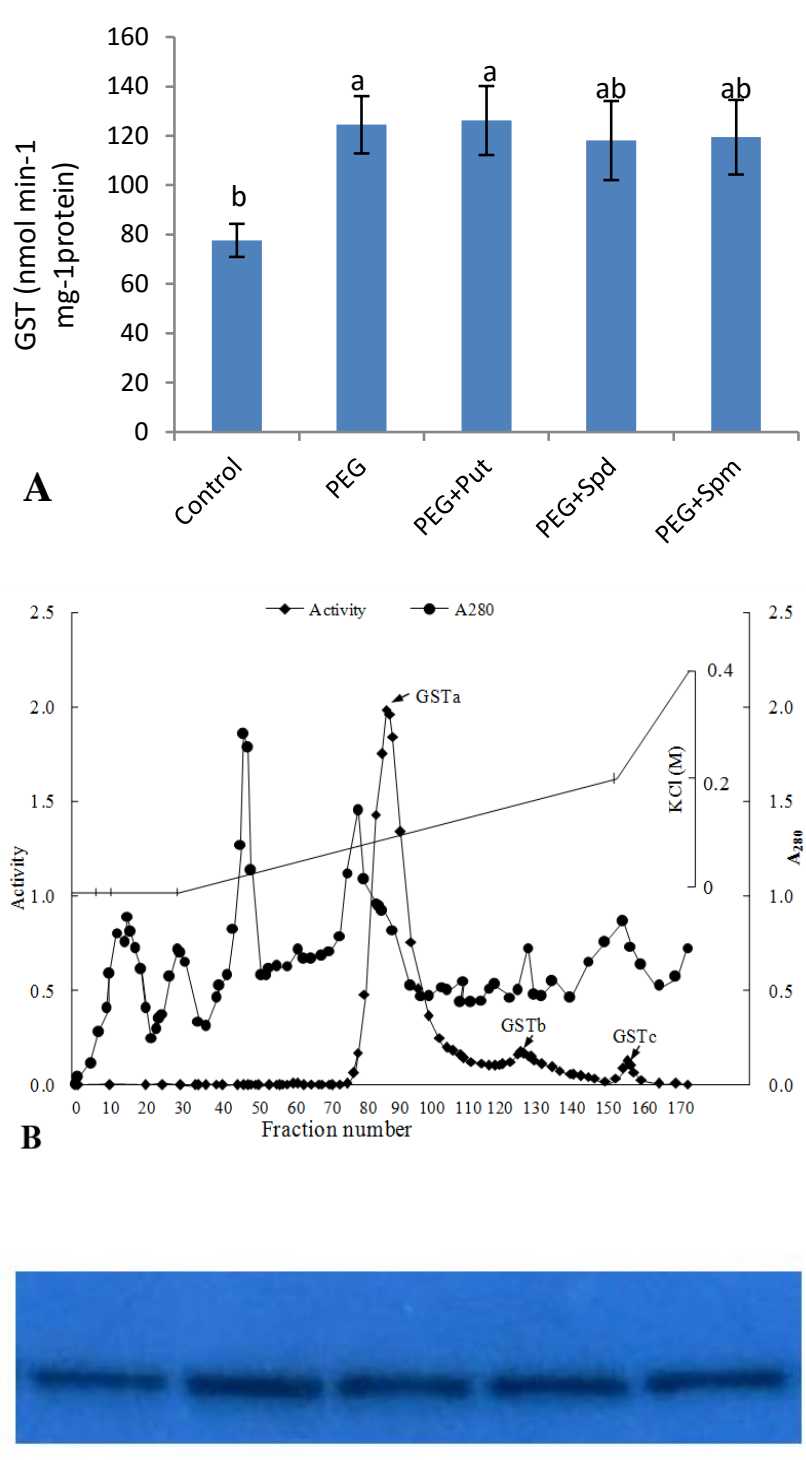

Control PEG PEG+Put PEG + Spd PEG + Spm

C

Figure 6

(A) Activity of GST in maize seedlings under PEG induced drought in presence of Pas, (B) Separation of GST by DEAE column chromatography, and (C) Western blotting of GSTa

Decreasing tendency of Gly-I and Gly-II and increased MG under drought (Figure 3B, 3C) ultimately suggested interaction with MG content under water stress, which showed consistency with many previous studies (Banu et al., 2010; Ghosh et al., 2014). As reasons behind this phenomenon it could be suggested that, increased rates of glycolysis under stress (Kaur et al., 2015) and/or deficiency in GSH limiting the production of hemithioacetal (Hossain et al., 2012) may act. Even PA supplementation did not show notable efficiency in decreasing MG concentration. Nahar et al. (2015) also documented failure of spd to increase Gly-I activity in mungbean significantly under low temperature stress.

\section{PAs Effect on Non-enzymic Antioxidant}

Present study observed decrease in AsA level under drought (Figure 4A). Several other studies (Sharma and Dubey, 2007 and Srivastava and Dubey, 2011) also observed altered AsA level in response to the level and type of environmental stress. The AsA level under environmental stresses depends on the balance between the rates and capacity of AsA biosynthesis and turnover related to antioxidant demand (Chaves et al., 2002). In this study, PAs implied positive influence on AsA concentration over that in drought. In stressed cells, DHA is produced in the second step of AsA oxidation or, from spontaneous mutation of transitory radical, MDHA by NADPH dependent enzyme, MDHAR activity (Asada, 1994). As being a short lived radical, DHA is either hydrolyzed irreversibly to 2, 3-diketogulonic acid or, reduced to AsA through DHAR enzyme catalyzed GSH recycling via the AsA-GSH cycle (Sharma et al., 2012). This study demonstrated inclined content of DHA under PEG induction (Figure 4B). Shalata et al. (2001) and Mittova et al. (2004) also showed consistency to our observation in regard to augmented amount of DHA in stress. However, PAs did not show significant activity in enervating AsA oxidation. GSH is one of the crucial antioxidants, for it protects macromolecules (i.e., proteins, lipids, DNA) either by the forming adducts directly with reactive electrophiles (glutathiolation) or, by donating proton in the presence of ROS or, organic free radicals, yielding GSSG (Asada, 1994). In present observation, GSH activity showed declining trend under drought (Figure 4D). This result showed consistency with (Hefny and Kader, 2009 and Tausz et al., 2004) as found in several crop species. In case of PA impact, GSH content increased. Verma and Mishra (2005) are in agreement with this observation on positive impact of PA (put) on GSH content. Foyer and Halliwell (1976) reported Put to maintain a high GSH/GSSG ratio, essential for the modulation AsA threshold level and activation of different $\mathrm{CO}_{2}$ fixing enzymes.

\section{PAs Effect on Enzymic Activities}

SOD provides the first line protection from cytotoxic $\mathrm{O}_{2}{ }^{-}$by converting it into $\mathrm{H}_{2} \mathrm{O}_{2}$. The $\mathrm{H}_{2} \mathrm{O}_{2}$ is then converted to $\mathrm{H}_{2} \mathrm{O}$ in presence of POD, CAT, APX, and GPX. SOD and POD activities were higher under drought (Figure 6A, 6B). Sharma and Dubey (2005) and Mishra et al. (2011) also reported increased SOD and POD activities under diversified stresses including drought. PAs application increased the SOD and POD activities (Figure 6A, 6B) suggesting the protective role of PAs from oxidative damage. Verma and Mishra (2005) and Sheokand et al. (2008) conferred increased SOD activity due to Put protecting the biomolecules from $\mathrm{O}_{2}{ }^{-}$attack. Besides, put could bind different antioxidant enzymes like SOD producing a covalent Put-SOD complex, which was 20 fold more membrane permeable than SOD alone and facilitate oxygenic protection in mammalian cells (Poduslo and Curran, 1996; Wengenack et al., 1997). However, in this study, Spd seemed to be more effective in SOD activity augmentation. Supportively, Chang et al. (2010) reported increased SOD activity for Spd exposure in cucumber seedling under salinity stress suggesting Spd to be mostly associated with stress tolerance among three major PAs (Put, Spd, and Spm). Higher POD activity in presence of PAs was in agreement with Moussa and Aziz (2008) and Wang et al. (2012). Verma and Mishra (2005) 
observed upsurge in POD activity with Put under high salinity. CAT could be the principal enzymic $\mathrm{H}_{2} \mathrm{O}_{2}$ scavenger in plants under abiotic stresses including drought, where the cellular $\mathrm{H}_{2} \mathrm{O}_{2}$ level becomes several fold higher than in plants grown under normal conditions (Nor'aini et al., 1997; Cheeseman, 2006). Present observation showed decreased CAT activity under drought induction (Figure 5C). Several previous studies (Corpas et al., 1993; Sharma and Dubey, 2005) reported decreased CAT activity in diversified stress condition as shown in different crop species. Declined CAT activity indicates that, under prospective state, CAT may not act as an effective $\mathrm{H}_{2} \mathrm{O}_{2}$ scavenger (Sharma and Dubey, 2005). Besides, this enzyme, although, has so a fast turnover rate but poses a relatively poor affinity for $\mathrm{H}_{2} \mathrm{O}_{2}$ and in light it undergoes photo-inactivation followed by degradation (Hertwig et al., 1992). However, in presence of PAs, CAT activity inclined sharply (Figure 5C). Similarly, Shi et al. (2013) also observed that, after salt and drought treatments, PAs treated seedlings exhibited significantly augmented CAT activity than those of nontreated seedlings. Verma and Mishra (2005) also reported increased CAT activity due to Put treatment. Besides, APX and GPX along with MDHAR and DHAR are important antioxidants in ascorbate-glutathione cycle in maintaining $\mathrm{H}_{2} \mathrm{O}_{2}$ as well as $\mathrm{GSH}$ and AsA (Apel and Hirt, 2004). Under drought, 50\% higher APX activity along with AsA oxidation (Figure 5D, 4A) suggested that AsA has participated in the degradation of $\mathrm{H}_{2} \mathrm{O}_{2}$ catalyzed by APX. Many researchers (Srarma and Dubey, 2005 and Han et al., 2009) also documented increased APX activity in different stress conditions. However, remarkable alteration in APX activity was not found under PA supplementation (Figure 5D). In GSH-dependent metabolism, $\mathrm{H}_{2} \mathrm{O}_{2}$ is metabolized by GPX where GSH is converted to GSSG. In this study, higher GPX activity under drought (Figure 5E) indicated a role of this enzyme in $\mathrm{H}_{2} \mathrm{O}_{2}$ metabolism using GSH (Figure 4D). Increased GPX activity in wheat under drought condition has been reported by Sayfzadeh and Rashidi (2010) while involvement of two GPX genes in $\mathrm{H}_{2} \mathrm{O}_{2}$ tolerance was reported by Zhai et al. (2013). GPX induction by PAs (Figure 5E) Figureured PAs role in $\mathrm{H}_{2} \mathrm{O}_{2}$ scavenging. GR, an NADPH-dependent enzyme, acts as catalyst for the reduction of GSSG to GSH and thus maintains high cellular GSH. In this study, GR activity increased under drought (Figure 5F) implying strong impact of GR on maintaining of GSH. Several studies also reported increased GR activity under stressed condition in different plant species (Sharma and Dubey, 2005; Maheshwari and Dubey, 2009). Present study showed induced GR activity in PAs application (Figure 5F). Verma and Mishra (2005) reported Put induced GR activity with increased ratio of NADP+ and NADPH and thus ensuring the availability of $\mathrm{NADP}+$ to accept electron resulting into lower flow of electron to $\mathrm{O}_{2}$ for ROS generation. Nahar et al. (2015) also reported higher GR activity in presence of Spd. Enzyme like MDHAR and DHAR have important role in in maintaining AsA contents in cell. In this study, the negative changes in MDHAR under drought (Figure 5G) suggested the possibility of maintaining AsA in maize seedlings, essential for maintenance of a balanced redox status or inactivation of MDHAR activity due to scarce NADPH (Hossain et al., 2011). This result consisted with findings reported by many workers such as Hasanuzzaman et al. (2012) and Fan et al. (2014) as conducted in many stressful conditions. However, MDHAR content increased under PAs treatment, particularly under Put supplementation. Spd effect was also appreciable which is in agreement with the investigation of Li et al. (2015), who reported increased tomato tolerance for increase in MDHAR activity in salinity- alkalinity stressed Spd supplementation compared to that in salinity- alkalinity stress. DHAR, a monomeric thiol enzyme, catalyzes the reduction of DHA to AsA using the electron provided by GSH, a reducing substrate and thus plays a key role in recycling AsA (Ushimaru et al., 1997). In this study, DHAR activity increased remarkably under drought (Figure 5H). These findings suggested that, DHAR has played a significant role in reducing oxidized DHA to AsA by oxidizing GSH to GSSG. Sharma and Dubey (2005) and Boo and Jung (1999) also found increase in DHAR content in response to level of dose as tested for cadmium tolerance. However, respect to PA effect, DHAR content decreased significantly in compared to stress (Figure 5H). Lower DHAR activity in presence of PAs is not clear. GST uses GSH for participating in detoxification of ROS, xenobiotics, and membrane lipid peroxidation. Maize GST was reported to have three component GST (Rohman et al., 2016), among which GST (GSTa) contained more than $90 \%$ of total activity (Figure 14C). The antibody of GSTa was used to examine the accumulation of the protein by Western blotting. This finding also confirmed the accumulation of GSTa in PEG induction (Figure 14A) and it seemed not to have positive effect of PAs in accumulation of the GST. Several other studies (Jogeswar et al., 2006; George et al., 2010) reported increased activity of GST in many stressful conditions, which might be due to regulation of flavonoid (Rohman et al., 2010).

\section{Conclusion}

Respect to our present study some conclusions are drawn, 1) Strong correlation between polyamine and stress concerned parameters has been evidenced, 2) Specially, Putrescine and Spermidine has been observed to be highly effective in mitigating stress severity, and 3) Though, in most of the cases, strong effectiveness of polyamine has been demonstrated, they have yet showed inconsistency with expected result.

\section{References}

Abaaszadeh P, Sharifi A, Lebaschi H, Moghadasi F. 2007. Effect of drought stress on proline, soluble sugars, chlorophyll and RWC level in Melissa officinalis. Irn J Med Plnt Res.23: 504-513.

Abou-Aziz AB, Kassas SE, Boutros BN, Sese AM, Soliman SS.1995. Flowering and fruit setting of Manfalouti pomegranate in response to soil moisture and irrigation regime. Assiut $\mathrm{J}$ Agric Sci.26: 129-147. 
Agastian P, Kingsley SJ, Vivekanandan M. 2000. Effect ofsalinity on photosynthesis and biochemical characteristics inmulberry genotypes.Photosynth. 38: 287-290.

Ahmad P, Azooz MM, Prasad MNV. 2012. Eco-physiology and responses of plants under salt stress. Eds. 1-24.

Anjum S, Xie X, Wang L, Saleem M, Man C, Lei W. 2011. Morphological, physiological and biochemical responses of plants to drought stress.Afric J Agric Res. 6: 2026-2032.

Apel K, Hirt H. 2004. Reactive oxygen species: metabolism, oxidative stress, and signal transduction. Ann Rev Plant Biol. 55: 373-399.

Arnon DI. 1949. Copper enzyme polyphenol oxides in isolated chloroplast in Beta vulgaris. Plant Physiol. 24: 1-15.

Asada K. 1994. Production and action of active oxygen species in photosynthetic tissues in Causes of Photooxidative Stress and Amelioration of Defense Systems in Plants. Foyer, C. H. and Mullineaux, P.M. Eds.77-104.

Asada K. 1999. The water-water cycle in chloroplasts: scavenging of active oxygen and dissipation of excess photons. Annu. Rev. Plant.Physiol. Plant Mol. Biol. 50: 601-639.

Banu MN, Hoque MA, Watanabe-Sugimoto M, Islam MM, Uraji M, Matsuoka K, Nakamura Y, Murata Y. 2010. Proline and glycine betaine ameliorated $\mathrm{NaCl}$ stress via scavenging of hydrogen peroxide and methylglyoxal but not superoxide or nitric oxide in tobacco cultured cells. BiosciBiotechnol Biochem.74: 2043-9.

Barrs HD, Weatherley PE. 1962. A re-examination of the relative turgidity technique for estimating water deficits in leaves. Aust J Biol Sci. 15: 413-428.

Bates L, Waldren RP, Teare ID. 1973. Rapid determination of free proline for water-stress studies.Plant Soi. 39: 205-207.

Boo YC, Jung J. 1999. Waterdeficit-Induced oxidative stress and antioxidative defenses in rice plants. J of Plant Physiol.155: $255-261$.

Bors W, Langebartels C, Michel C, Sandermann JH. 1989. Polyamine as radical scavengers and protectants against ozone damage.Phytoche. 28: 1589-1595.

Bradford MM. 1976. A rapid and sensitive method for quantification of microgram quantities of protein utilizing the peinciple of proteins-dye binding.Anal Biochem. 72: 248-254.

Chang CW, Chou FC, Hung PY. 2010. Evaluation of bioaerosol sampling techniques for Legionella pneumophila coupled with culture assay and quantitative PCR. J. Aerosol Sci. 41: 10551065.

Chattopadhayay MK, Tiwari BS, Chattopadhayay G, Bose A, Sengupta DN, Ghosh B. 2002. Protective role of exogenous polyamines on salinity-stressed rice Oriza sativa) plants. Physiol Plant. 116: 192-199.

Chaves MM, Pereira JS, Maroco J, Rodrigues Ml, Ricardo CPP, Osório Ml, Carvalho I, Faria T, Pinheiro C. 2002. How Plants Cope with Water Stress in the Field? Photosynthesis and Growth, Photosynthesis and growth.Ann Bot. 89: 907-916., https://doi.org/10.1093/aob/mcf105

Cheeseman JM. 2006. Hydrogen peroxide concentration in natural conditions. J Exp Bot. 67: 2435-2444.

Corpas FJ, G'omez M, Herna'ndez JA, delRi'o LA. 1993. Metabolism of activated oxygen in peroxisomes from two Pisum sativum L. cultivars with different sensitivity to sodium chloride. J Plant Physiol. 141:160-165.

Csiszar J, Lantos E, Tari I, Madoșa E, Wodala B, Vashegyi A, Horváth JF, Pécsváradi A. Szabó M, Bartha B, Gallé Á, Lazăr A, Coradini G, Staicu M, Postelnicu S, Mihacea S, Nedelea G, Erdei L. 2007. Antioxidant enzyme activities in Allium species and their cultivars under water stress. Plant Soil Environ. 53: 517-523.

D'souza MR, Kokila S, Devaraj VR. 2014. Polyamine Levels in Leaves of Hyacinth Bean (Lablab purpureus) and Their Relation to Drought-Tolerance. Wor App Sci J. 32: 2398-2402.

Dejian H, Boxin O, Ronald LP. 2005. The chemistry behind antioxidant capacity assays. Journal of agricultural and food chemistry 53.6 (2005): 1841-1856

Delauney AJ, Verma DPS. 1993. Proline biosynthesis and osmoregulation in plants. The Plant J. 4: 215-223.
Doderer A, Kokkelink I, van der Veen S, Valk BE, Schram AW, Douma AC. 1992. Purification and characterization of two lipoxygenaseiso enzymes from germinating barley. BiochimBiophysActa. 1120: 97-104.

Elia AC, Galarini R, Taticchi MI, Dorr AJM, Mantilacci L. 2003. Antioxidant responses and bioaccumulation in Ictalurusmelas under mercury exposure. Ecotoxicol Environ Saf. 55: 162-167.

Elstner EF, Heupel A. 1976. Inhibition of nitrite formation from hydroxyl ammonium-chloride: a simple assay for superoxide dismutase. Anal.Biochem. 70: 616-620.

Fan H-F, Ding L, Du C-X, Wu X. 2014. Effect of short-term water deficit stress on antioxidative systems in cucumber seedling roots. Botanic Stud.55: 46

Foyer CH, Halliwell B. 1976. The presence of glutathione and glutathione reductase in chloroplasts: A proposed role in ascorbic acid metabolism.Planta.133: 21-25.

Galston AW, Sawhney RK. 1990. Polyamines in Plant Physiology.Plant Physiol. 94: 406-410.

George S, Venkataraman G, Parida A. 2010. A chloroplast-localized and auxin induced glutathione S-transferase from phreatophyte Prosopis juliflora confer drought tolerance on tobacco. J Plant Physiol. 167: 311-318.

Ghosh A, Singla-Pareek SL, Pareek A, Sopory SK. 2014. A glutathione responsive rice glyoxalase II, OsGLYII-2, functions in salinity adaptation by maintaining better photosynthesis efficiency and anti-oxidant pool. The Plant J. 80: 93-105.

Gill SS, Narendra T. 2010. Reactive oxygen species and antioxidant machinery in abiotic stress tolerance in crop plants. Plant physiology and biochemistry 48.12 (2010): 909-930.

Halliwell B, Gutteridge JMC. 1989. Free Radicals in Biology and Medicine, Oxford University Press, Oxford, UK, Eds. 1-704.

Han C, Liu Q, Yang Y. 2009. Short-term effects of experimental warming and enhanced ultraviolet-B radiation onphotosynthesis and antioxidant defense of Picea asperataSeedlings. Plant Growth Regul. 58: 153-162.

Hasanuzzaman M, Hossain MA, da Silva JAT, Fujita M. 2012. Plant responses and tolerance to abiotic oxidative stress: antioxidant defenses is a key factors. In: Bandi V, Shanker.

Heath RL, Packer L. 1968. Photoperoxidation in isolated chloroplasts. I. Kinetics and stoichiometry of fatty acid peroxidation.Arch BiochemBiophys. 125: 189-198.

Hefny M, Abdel-Kader DZ. 2009. Antioxidant-enzyme system as selection criteria for salt tolerance in forage sorghum genotypes (Sorghum bicolor L. Moench)," in Salinity an Water Stress, Ashraf, M. Ozturk, M. and Athar, H. R. Eds. Springer. 25-36.

Hemeda HM, Klein BP. 1990. Effects of naturally occurring antioxidants on peroxidase activity of vegetable extracts. Food Sci. 55: 184-186.

Hertwig B, Streb P, Feierabend J. 1992. Light dependency of catalase synthesis and degradation in leaves and theinfluence of interfering stress conditions. Plant Physiol. 100: 1547-1553.

Hoque MA, Okuma E, Banu MNA, Nakamura Y, Shimoishi Y, Murata Y. 2006. Exogenous proline mitigates the detrimental effects of salt stress more than exogenous betaine by increasing antioxidant enzyme activities. J. Plant Physiol. 164: 553-561.

Hossain MA, Hasanuzzaman M, Fujita M. 2010. Up-regulation of antioxidant and glyoxalase systems by exogenous glycine betaine and proline in mungbean confer tolerance to cadmium stress. PhysiolMolBiol Plants.16: 259- 272.

Hossain MA, Jaime A, Da Silva T, Fujita M. 2011. Glyoxalase System and Reactive Oxygen Species Detoxification System in Plant. Abiotic Stress Response and Tolerance: An Intimate Relationship. Shanker, A. Eds. 235-266.

Hossain MA, Piyatida P, Teixeira da Silva JA Fujita M. 2012. Molecular mechanism of heavy metal toxicity and tolerance in plants: central role of glutathione in detoxification of reactive oxygen species and methylglyoxal and in heavy metal chelation. J Bot. 37 pages.

Jogeswar G, Pallela R, Jakka NM, Reddy PS, VenkateswaraRao J, Sreenivasulu N, KaviKishor PB. 2006. Antioxidative response in different sorghum species under short-term salinity stress. Acta Physiol. Plant. 28: 465-475. 
Kaur C, Kushwaha HR, Mustafiz A, Pareek A, Sopory SK, SinglaPareek SL. 2015. Analysis of global gene expression profile of rice in response to methylglyoxal indicates its possible role as a stress signal molecule. Front. Plant Sci. 6: 682.

Kitada M, Igarashi K, Hirose S, Kitagawa H. 1979. Inhibition by polyamines of lipid peroxide formation in rat liver microsomes. Bioche .Biophys Res Commun. 87: 388-394.

Kotzabasis K, Fotinou C, Roubelakis-Angelaki, KA, Ghanotakis D. 1993. Polyamines in the photosynthetic apparatus. Photosyn Res. 38: 83-88.

Kubis J. 2006. Exogenous spermidine alters in different way membrane permeability and lipid peroxidation in water stressed barley leaves. Physiol Plant. 28: 27-33.

Laemmli UK. 1970.Cleavage of Structural Proteins during the Assembly of the Head of Bacteriophage T4.Nature. 227: 680 685.

Lee TM, Liu CH. 1999. Correlation of decreases calcium contents with proline accumulation in the marine green macroalga Ulva fasciata exposed to elevated $\mathrm{NaCl}$ contents in seawater. J Exp Bot. 50:1855-1862.

Lester GE. 2000. Polyamines and their cellular antisenescence properties in honey dew musk melon fruit. Plant Sci. 160: 105112.

Liu J-H, Kitashiba H, Wang J, Ban Y, Moriguchi T. 2007. Polyamines and their ability to provide environmental stress tolerance to plants. Plant.Biotechnol. 24: 117-26.

Logini B, Scartazza A, Brugnoli E, Navari-Izzo F. 1999. Antioxidative defense system, pigment composition, and photosynthetic efficiency in two wheat cultivars subjected to drought. Plant Physiol. 119: 1091-1099.

Maheshwari R, Dubey RS. 2009. Nickel-induced oxidative stress and the role of antioxidant defence in rice seedlings. Plant Growth Regul. 59:1,37-49.

Mishra S, Jha AB, Dubey RS. 2011. Arsenite treatment induces oxidative stress, upregulates antioxidant system, and causes phytochelatin synthesis in rice seedlings. Protoplasma. 248: $565-577$.

Mittler R. 2002. Oxidative stress, antioxidants and stress tolerance. Trend Plant Sci.7: 405-410.

Mittova V, Guy M, Tal M, Volokita M. 2004. Salinity up-regulates the antioxidative system in root mitochondria and peroxisomes of the wild salt-tolerant tomato pecies Lycopersicon pennellii. OxfJSci\& MathJ Exp Bot. 55: 1105-1113.

Moussa R, Abdel-Aziz SM. 2008. Comparative response of drought tolerant and drought sensitive maize genotypes to water stress.Aust J Crop Sci. 1: 31-36.

Nakano Y, Asada K. 1981. Hydrogen peroxide is scavenged by ascorbate-specific peroxidase in spinach choroplast. Plant Cell Physiol. 22:867-880.

Navakoudis E, Lütz C, Langebartels C, Lütz-Meindl U, Kotzabasis K. 2003.Ozone impact on the photosynthetic apparatus and the protective role of polyamines.BiochimBiophysicActaBioenergetic, 1621: 160-169.

Noctor G, Foyer CH. 1998. Ascorbate and glutathione: keeping active oxygen under control. Annu. Rev. Plant. Biol. 49: 249279.

Nor'aini MF, Robert PF, Roy HB. 1997. Salinity, oxidative stress and antioxidant responses in shoot cultures of rice. J Exp Bot. 48: 25-331.

Parida AK, Dagaonkar VS, Phalak MS, Umalkar GV, Aurangabadkar LP. 2007. Alterations in photosynthetic pigments, protein and osmotic components in cotton genotypes subjected to short-term drought stress followed by recovery. Plant Biotechnol Rep. 1: 37-48.

Paul A, Panneerselvam R. 2014. ROS Scavenging System, Osmotic Maintenance, Pigment and Growth Status of Panicum sumatrense Roth.Under Drought Stress. Cell BiochemBiophys. 68: 587-595.

Poduslo JF, Curran GL. 1996. Increased permeability of superoxide dismutase at the blood-nerve and blood - brain barriers with ratined enzymatic activity after covalent modification with naturally occurring putrescine. J Neurochem. 67: 734-741.
Principato GB, Rosi G, Talesa V, Giovannini E, Uotila C. 1987. Purification and characterization of two forms of GII from the liver and brain of Wistar rats. BiochimicBiophysActa. 911: 349355.

Radhakrishnan R, Lee IJ. 2014. Effect of Low Dose of Spermidine on Physiological Changes in Salt_Stressed Cucumber Plants1.Russ J Plant Physiol. 61:,90-96.

Ramanjulu S, Sudhakar C. 2000. Proline metabolism during dehydration in two mulberry genotypes with contrasting drought tolerance.J Plant Physiol. 157: 81-85.

Rohman A, Riyanto S, Yuniarti N, Saputra WR, Utami R, Mulatsih W. 2010. Antioxidant activity, total phenolic, and total flavaonoid of extracts and fractions of red fruit (Pandanus conoideus Lam).Int Food Res J. 17: 97-106.

Rohman MM, Talukder MZA, Hossain MG, Uddin MS, Amiruzzaman M, Biswas A, Ahsan AFMS, Chowdhury MAZ. 2016. Saline sensitivity leads to oxidative stress and increases the antioxidants in presence of proline and betaine in maize (Zea mays L.) inbred. Plant Omics J. 9: 35-47.

Roy Choudhury S, Ghosh M, Mandal A, Chakravorty D, Pal M, Pradhan S, Goswami A. 2011. Surface-modified sulfur nanoparticles: an effective antifungal agent against Aspergillus niger and Fusarium oxysporum. ApplMicrobiolBiotechnol. 90: 733-743.

Sairam RK, Tyagi A. 2004. Physiology and molecular biology of salinity stress tolerance in deficient and cultivated genotypes of chickpea. Current Sci. 86: 407-421.

Saleethong P, Sanitchon J, Kong-ngern K, Theerakulpisut P. 2011. Pretreatment with spermidine reverses inhibitory effects of salt stress in two rice (Oryza sativa L.) cultivars differing in salinity tolerance. Asian J Plant Sci. 10: 245-254.

Sayfzadeh S, Rashidi M. 2010. Effect of Drought Stress on Antioxidant Enzyme Activities and Root Yield of Sugar Beet (Beta vulgaris). Am-Euras J Agric Environ Sci. 9: 223-230.

Shalata A, Mittova V, Volokita M, Guy M, Tal M. 2001. Response of the cultivated tomato and its wild salt-tolerant relative Lycopersicon pennelliito salt-dependent oxidative stress: The root antioxidative system. Physiol Plant.112: 487-494.

Sharma P, Dubey RS. 2005. Drought induces oxidative stress and enhances the activities of antioxidant enzymes in growing rice seedlings. Plant Growth Regul. 46: 209-221.

Sharma P, Dubey RS. 2007. Involvement of oxidative stress and role of antioxidative defense system in growing rice seedlings exposed to toxic concentrations of aluminum. Plant Cell Rep. 26: 2027-2038.

Sharma P, Jha AB, Dubey RS, Pessarakli M. 2012. Reactive Oxygen Species, Oxidative Damage, and Antioxidative Defense Mechanism in Plants under Stressful Conditions. J Bot. 2012: 26 pages.

Shen W, Nada K, Tachibana S. 2000. Involvement of polyamines in the chilling tolerance of cucumber cultivars. Plant Physiol.124: 431-439.

Sheokand S, Kumar A, Sawhney V. 2008. Effect of nitric oxide and putrescine on antioxidative responses under $\mathrm{NaCl}$ stress in chickpea plants. Physiol. Mol. Biol. Plants 14: 355-362.

Shi H, Ye T, Chan Z. 2013. Comparative Proteomic and Physiological Analyses Reveal the Protective Effect of Exogenous Polyamines in the Bermuda grass (Cynodon dactylon) Response to Salt and Drought Stresses. J. Proteome Res.12: 4951-4964

Singla-Pareek SL, Yadav SK, Pareek A, Reddy MK, Sopory SK. 2008. Enhancing salt tolerance in a crop plant by overexpression of glyoxalase II. Transgenic. Res. 17: 171-180.

Spitz DR, Oberley LW. 1989. An assay for superoxide dismutase activity in mammalian tissue homogenates. Anal Biochem. 179: $8-18$.

Srivastava S, Dubey RS. 2011. Manganese-excess induces oxidative stress, lowers the pool of antioxidants and elevates activities of key antioxidative enzymes in rice seedlings. Plant Growth Regul.1-16.

Sundaresan S, Sudhakaran PR. 1995. Water stress-induced alterations in proline metabolism of drought-susceptible and tolerant cassava (Manihot esculenta) cultivars.Plant Physiol. 94: 635-642. 
Tadolini B. 1988. Polyamine inhibition of lipoperoxidation. The influence of polyamines on iron oxidation in the presence of compounds mimicking phospholipid polar heads.Biochem J. 249: 33-36.

Tausz M, `Sircelj H, Grill D. 2004 The glutathione system as a stress marker in plant ecophysiology: is a stress-response concept valid? J Exp Bot. 55: 1955-1962.

Thornalley PJ. 1990. The glyoxalase system: new developments towards functional characterization of a metabolic pathway fundamental to biological life. Biochem J. 269:1-11.

Tiburcio AF, Besford RT, Capell T, Borrell A, Testillano PS, Risuen o MC. 1994. Mechanisms of polyamine action during senescence responses induced by osmotic stress. J Exp Bot. 45: $1789-800$.

Ushimaru T, Maki Y, Sano S, Koshiba K, Asada K, Tsuji H. 1997. Induction of Enzymes Involved in the Ascorbate-Dependent Antioxidative System, Namely, Ascorbate Peroxidase,Monodehydroascorbate Reductase and Dehydroascorbate Reductase, after Exposure to Air of Rice (Oryza sativa) Seedlings Germinated under Water. Plant Cell Physiol. 38: 541-549.

Verma S, Mishra SN. 2005. Putrescine alleviation of growth in salt stressed Brassica juncea by inducing antioxidative defense System. J Plant Physiol. 162: 669-77.

Wang S, Liang D, Li C, Hao Y, Ma F, Shu H. 2012. Influence of drought stress on the cellular ultrastructure and antioxidant system in leaves of drought-tolerant and drought-sensitive apple rootstocks. Plant PhysiolBiochem. 51: 81-89.
Wengenack TM, Curran GL, Olson EE, Poduslo JF. 1997. Putrescine-modified catalase with preserved enzymatic activity exhibits increased permeability at the blood nerve and bloodbrain barriers. Brain Res.767: 128-135.

Wild CJ, Davis MH, Johnsrude IS. 2012. Human auditory cortex is sensitive to the perceived clarity of speech. Neuroimage. 60: $1490-1502$.

Xie YF, Shen H, Li M. 1999. Effect of acid stress on endogenous polyamines and active oxygen metabolism of woody plants. $\begin{array}{llll}\text { Scientia } & \text { Silvae } & \text { Sinica.35: }\end{array}$ http://europepmc.org/abstract/cba/324803

Yadav SK, Singla-Pareek SL, Ray M, Reddy MK, Sopory SK. 2005. Methylglyoxal levels in plants under salinity stress are dependent on glyoxalase I and glutathione. BiochemicBiophys Res Comm. 337: 61-67.

Yancey PH, Clark ME, Hand SC, Bowlus RD, Somero GN. 1982. Living with water stress: Evolution of osmolyte systems. Sci. 217: 1214-1222.

Yu F, Morin X, Kaushik R, Bahri S, Yang X, Chia W. 2003. A mouse homologue of Drosophila pins can asymmetrically localize and substitute for pins function in Drosophila neuroblasts. J. Cell Sci. 116: 887--896.

Zhai C-Z, Zhao L, Yin L-J, Chen M, Wang Q-Y. 2013. Two Wheat Glutathione Peroxidase Genes Whose Products Are Located in Chloroplasts Improve Salt and $\mathrm{H} 2 \mathrm{O} 2$ Tolerances in Arabidopsis. PLoS ONE 8: 10-21.

Zhang J, Kirkham MB. 1996. Antioxidant response todrought in Sunflower and Sorghum seedlings.New Phytologist.132: 361373. 